О. В. Зайцева, С. Г. Шандренко, М. М. Великий ІНСТИТУТ БІОХІМІЇ ІМЕНІ О.В. ПАЛЛАДІНА НАН УКРАЇНИ, КИЇВ

\title{
ВПЛИВ НІТРОЗАТИВНОГО СТРЕСУ НА МІНЕРАЛЬНИЙ МЕТАБОЛІЗМ КІСТКОВОЇ ТКАНИНИ ЩУРІВ ЗА УМОВ АЛІМЕНТАРНОГО ОСТЕОПОРОЗУ
}

На моделі аліментарного остеопорозу дослідили вплив індукованого нітрозативного стресу на метаболізм кісткової тканини щурів. Як індуктор нітрозативного стресу використовували вакцину БЦЖ. Показано, що вітамін $D_{3}$-дефіцитний остеопороз за введення вакцини БЦЖ призводить до оксидативно-нітрозативного стресу в щурів, розвиток якого реєстрували за накопиченням NO в лейкоцитах, зміною вмісту альдегідів, продуктів пероксидного окиснення ліпідів, SH-груп низькомолекулярних сполук та карбонільних груп протеїнів. Встановлено, що інтенсифікація синтезу NO на тлі остеопорозу викликає зміни інтенсивності мінерального обміну кісткової тканини. Стабілізується рівень кальцію та знижується активність лужної фосфатази. Отримані результати свідчать про те, що високі концентрації NO впливають на функціонування клітин кісткової тканини та гальмують процес резорбції кістки.

КЛЮЧОВІ СЛОВА: остеопороз, вітамін $\mathbf{D}_{3}$, БЦЖ, нітрозативний стрес, кісткова тканина.

ВСТУП. На сьогодні відомо, що NO має поліфункціональну фізіологічну дію [11]. Цей вільний радикал здатен проявляти як активуючу, так і інгібуючу дії різних метаболічних процесів, що перебігають в організмі [8]. Генерація NO зумовлюється різними типами NO-синтаз: нейрональною (nNOS, тип I), індуцибельною (iNOS, тип II) та ендотеліальною (eNOS, тип III). Ензими як субстрат використовують L-аргінін та молекулярний кисень [2].

В останні роки стало очевидним, що NO регулює функціонування клітин кісткової тканини [20]. Ізоформа eNOS постійно експресується в кістковій тканині, й невеликі концентрації NO, що утворюються при цьому, $є$ необхідними для нормального функціонування остеокластів. Ізоформа iNOS експресується в клітинах кісткової тканини у відповідь на розвиток патологічних процесів, зокрема запалення. Прозапальні цитокіни, такі, як IL-1 та TNF (фактор некрозу пухлини), інтерферони [18] або введення бактеріального ліпополісахариду (вакцина БЦЖ) [10] зумовлюють активацію гена iNOS, що призводить до гіперпродукування NO і розвитку нітрозативного стресу. Утворений NO може мати як прямий вплив на клітини організму, так і опосередкований, який реалізується через дію продуктів реакції NO 3 ๑ О. В. Зайцева, С. Г. Шандренко, М. М. Великий, 2015. іншими молекулами, такими, як кисень чи супероксид, відіграючи, таким чином, провідну роль у патофізіології запалення та оксидативно-нітрозативного стресу [15]. Оксид азоту, що утворюється в результаті індукції iNOS, сприяє ядерній транслокації фактора транскрипції NFкB у попередниках остеокластів та є причиною NO-індукованого апоптозу останніх [18]. Високі концентрації NO здатні безпосередньо інгібувати формування та активність клітин кісткової тканини [14, 23].

Незважаючи на численні дослідження, значення NO в системній регуляції гомеостазу кісткової тканини за умов різних патологій, у тому числі й остеопорозу, не цілком зрозуміле. Тому метою даної роботи було дослідити вплив індукованого нітрозативного стресу на зміну основних показників мінерального обміну кісткової тканини при аліментарному (вітамін $D_{3}$-дефіцитному) остеопорозі.

МЕТОДИ ДОСЛІДЖЕННЯ. Дослідження проводили на білих щурах-самицях лінії Вістар масою 80 г. Експериментальну модель Dгіповітамінозу викликали, утримуючи тварин на синтетичному раціоні без вітаміну $D_{3}$ зі збалансованим вмістом кальцію (1,2%) та фосфору $(0,7 \%)$ протягом 45 діб. Щурів поділили на три групи по п'ять тварин у кожній. Контрольних 
тварин протягом місяця утримували на вітамін $D_{3}$-збалансованій дієті. Щурів 2-ї та 3-ї груп протягом 45 діб утримували на $\mathrm{D}_{3}$-гіповітамінозному раціоні. Додатково тваринам 3-ї групи на 30 день експерименту для індукції нітрозативного стресу інтраперитонеально ввели 0,5 мг/кг мікобактерій вакцинного штаму БЦЖ-1. Встановленим фактом є те, що ін'єкція щурам вакцини БЦЖ суттєво посилює ендогенний синтез NO. Це посилення досить суттєве вже через 6 год та максимальне на 10-й день після введення БЦЖ, далі воно поступово зменшується і до 20-го дня зникає [10]. Тому тварин виводили з експерименту на 15 день після введення вакцини БЦЖ.

Для аналізу використовували кров, печінку та стегнову кістку піддослідних тварин.

Остеометричні дослідження стегнової кістки щурів проводили згідно з В. П. Олексієвим [1]. Рівень кальцію, фосфату та загальну активність лужної фосфатази визначали у плазмі крові за допомогою стандартних наборів фірми “Філісіт-Діагностика" (Україна).

Рівень NO в лейкоцитах щурів визначали 3 використанням діамінофлуоресцеїну діацетату (DAF-2DA) ("Sigma”, США). До 1 мл виділеної суспензії лейкоцитів додавали 2 мкл DAF-2DA (5 mM) та інкубували 30 хв при $37^{\circ} \mathrm{C}$ у темряві. Продукцію NO оцінювали на протоковому цитометрі COULTER EPICS XL ("Beckman Coulter", США).

Загальний вміст альдегідів у зразках печінки та крові визначали пурпалдним методом [19]. Осадження протеїнів проводили шляхом додавання насиченого розчину $\mathrm{Ba}(\mathrm{OH})_{2}$ та $20 \%$ розчину $\mathrm{ZnSO}_{4}$. Після цього центрифугували 10 хв при $4000 \mathrm{~g}, 4^{\circ} \mathrm{C}$. До 1 мл супернатанту додавали 0,5 мл розчину 0,1 \% пурпалду ("Sigma", США) в $2 \mathrm{~N} \mathrm{NaOH.} \mathrm{Через} 15$ хв додавали 0,5 мл 0,07 \% перйодату натрію (“Альфарус", Україна). Оптичну густину забарвленого розчину визначали при довжині хвилі 550 нм за допомогою спектрофотометра " $\mu$ Quant" ("Biotek", США). Як стандарт використовували розчин формальдегіду.

Інтенсивність процесів пероксидного окиснення ліпідів (ПОЛ) у плазмі крові визначали за накопиченням тіобарбітуратреагуючих (ТБКреагуючих) продуктів [17]. Протеїни плазми осаджували 20 \% трихлороцтовою кислотою (ТХO). Центрифугували зразки 15 хв при 2200 g, 4 으. До 200 мкл супернатанту додавали 250 мкл 0,67 \% розчину тіобарбітурової кислоти (ТБК) ("Альфарус", Україна). Зразки витримували 20 хв на водяній бані, що кипить, охолоджували та вимірювали оптичну густину при довжині хвилі 532 нм за допомогою спектрофотометра " $\mu$ Quant" ("Biotek", США).

Вміст SH-груп низькомолекулярних сполук визначали в печінці за реакцією з о-фталевим альдегідом [13]. Протеїни осаджували 6 \% розчином ТХO. Центрифугували 10 хв при 2200 g, $4{ }^{\circ} \mathrm{C}$. До 10 мкл надосаду додавали 180 мкл натрій-фосфатного буфера та 10 мкл $1 \%$ розчину о-фталевого альдегіду ("Fluka", Австрія). Інкубували 15 хв при $37^{\circ} \mathrm{C}$ у темряві. Вимірювання проводили при $\lambda_{\text {ex }} 360$ нм та $\lambda_{\text {em }}$ 420 нм за допомогою флуориметра FLx800 ("Biotek", США).

Вміст карбонільних груп, модифікованих 2,4-динітрофенілгідразином, у протеїнах плазми крові визначали специфічними антитілами Rabbit Anti-DNP (2,4-динітрофенілгідразон) Antibody ("Sigma", США) у твердофазному імуноферментному аналізі (т-ІФА) за стандартною методикою [12]. Оптичну густину визначали при довжині хвилі 490 нм за допомогою спектрофотометра " $\mu$ Quant" ("Biotek", США).

Активність супероксиддисмутази (СОД) детектували хемілюмінесцентним методом за інгібуванням швидкості утворення супероксидного радикала системою ксантин-ксантиоксидаза в бікарбонатному буфері (pH 10,2). За одиницю активності ензиму брали інгібування швидкості утворення $\mathrm{O}_{2}$ на 50 \%.

Активність каталази визначали за швидкістю розкладання пероксиду гідрогену та виражали у мкмолях розкладеного пероксиду за 1 хв на 1 мг протеїну.

Вміст протеїнів визначали методом Бредфорд.

Усі маніпуляції з тваринами проводили, дотримуючись вимог Європейської конвенції про захист хребетних тварин, що використовуються для дослідних та інших наукових цілей (Страсбург, 1986) та Загальних етичних принципів експериментів на тваринах (Київ, 2001).

Експериментальні дані обробляли методами варіаційної статистики з використанням t-критерію Стьюдента у програмі Excel (вірогідними вважали відмінності за р<0,05).

РЕЗУЛЬТАТИ Й ОБГОВОРЕННЯ. ЯК УЖе було показано в попередніх роботах, за умов аліментарної форми остеопорозу знижується вміст 250HD у сироватці крові, порушуються метаболічні процеси в кістковій тканині [7]. Розвиток остеопорозу підтверджено результатами остеометричних та біохімічних досліджень [3, 5].

У проведеній експериментальній роботі в щурів, яких утримували на D-гіповітамінозному 
раціоні протягом двох місяців для моделювання остеопорозу, відбулися зниження загальної маси тіла на 57 \%, зменшення маси і вертикального діаметра головки стегнової кістки на 47 та 14 \% відповідно, а також скорочення довжини стегнової кістки на 32 \% відносно контрольних тварин. Дефіцит вітаміну $\mathrm{D}_{3}$ або порушення його обміну зумовили розвиток гіпокальціємії, яка супроводжувалася яскраво вираженою гіпофосфатемією. Так, у плазмі крові щурів з розвиненим аліментарним остеопорозом загальний вміст кальцію знизився на $23 \%$, а вміст неорганічного фосфату - на $79 \%$. Важливо також відмітити, що активність лужної фосфатази в щурів з аліментарним остеопорозом підвищилася більше ніж у 2 рази. Отримані дані підтверджують адекватність обраної моделі для розвитку остеопорозу.

Відомо, що NO, залежно від його концентрації, може як стимулювати, так і інгібувати метаболізм кісткової тканини [18, 23]. Тому головним завданням даного дослідження було визначити вплив гіперпродукування NO в результаті посиленої експресії гена iNOS на зміну основних показників мінерального обміну кісткової тканини.

Високі (понад 1 мкмоль [21]) концентрації NO сприяють розвитку оксидативно-нітрозативного стресу, за якого виснажуються антиоксидантні й репаруючі ДНК системи та посилюється реалізація дії NO [11]. На сьогодні безпосереднє визначення рівня NO в біологічних зразках $є$ проблемним. Це пов'язано з методичними труднощами, що виникають при дослідженні обміну NO і його властивостей, зокрема: радикальна природа, обмежений термін життя (декілька секунд) та радіус дії, взаємодія із залізом, $\mathrm{O}_{2}$, а особливо із супероксидом $\left(\mathrm{O}_{2}\right)$ [16]. Тому для більш точного визначення NO було обрано чуттєвий метод з використанням барвника DAF-2DA. Проникаючи через мембрану клітини, DAF-2DA деацилюється неспецифічними цитозольними естеразами до DAF-2, який вступає в реакцію з $\mathrm{N}_{2} \mathrm{O}_{3}$ (продукт реакції NO з киснем) та утворює високофлуоресцентне похідне триазолофлуоресцеїн [22]. Аналіз цитофлуорограм (рис. 1, А I, II, III; Б) показав, що в щурів із розвиненим остеопорозом відбулося достовірне підвищення рівня NO в лейкоцитах у 2,5 раза відповідно до контрольного значення.

Отримані результати можна пояснити тим, що недостатнє забезпечення організму вітаміном $\mathrm{D}_{3}$ супроводжується розвитком оксидативного стресу, за якого прооксидантні процеси переважають над активністю антиоксидантних систем із посиленим утворенням активних форм кисню та азоту [7]. Індукція нітрозативного стресу після введення вакцини БЦЖ призвела до зростання рівня NO майже в 2 рази порівняно з групою щурів із розвиненим D-гіповітамінозом (рис. 1, В), що підтвердило посилення продукування NO в організмі тварин.

Додатково визначали маркери, які характеризують розвиток оксидативно-нітрозативних процесів в організмі щурів з аліментарним остеопорозом та індукованим нітрозативним стресом. Активні форми кисню та азоту можуть проявляти в організмі регуляторну або пошкоджувальну дію. Токсична дія активних форм кисню та азоту реалізується при станах оксидативно-нітрозативного стресу, які супроводжуються значною інтенсифікацією вільнорадикальних процесів та зниженням активності антиоксидантних систем. За умов аліментарного остеопорозу розвиток оксидативно-нітрозативного стресу підтверджується значними змінами вмісту продуктів окисної модифікації протеїнів [4] та ПОЛ. За різних патологічних станів, зокрема остеопорозу, окисна модифікація протеїнів є одним із маркерів оксидативно-нітрозативного стресу [6]. Окисній модифікації піддаються майже всі амінокислотні залишки, що може викликати утворення додаткових внутрішньо- та міжмолекулярних зшивок, агрегацію і фрагментацію протеїнів, зміну їх властивостей тощо [4, 7]. Результати, наведені в таблиці 1, вказують на те, що за умов D-гіповітамінозу вміст карбонільних груп протеїнів у плазмі крові щурів збільшився на 36 \% порівняно з контрольними тваринами.

Спостерігали підвищення загального рівня альдегідів у плазмі крові та печінці тварин на 33 і 37 \% відповідно (табл. 1), а також збільшення рівня ТБК-реагуючих продуктів у плазмі крові на $60 \%$, що свідчило про суттєве посилення процесів ПОЛ. Також відбулося зниження на 77 \% вмісту SH-груп низькомолекулярних сполук у печінці щурів із розвиненим аліментарним остеопорозом. Активність основних ензимів антиоксидантного захисту, таких, як СОД і каталаза, зросла за умов аліментарного остеопорозу в 4 та 1,6 раза відповідно (табл. 1), що вказувало на розвиток оксидативно-нітрозативного стресу.

У щурів із додатково індукованим нітрозативним стресом досліджувані показники залишилися майже на тому ж рівні, що й у щурів з аліментарним остеопорозом. Отримані результати можна пояснити тим, що високі концентрації NO, які утворюються в результаті індукції нітрозативного стресу, здатні пригнічувати подальшу експресію iNOS. У роботі [9] показано, що NO ендогенного походження, 

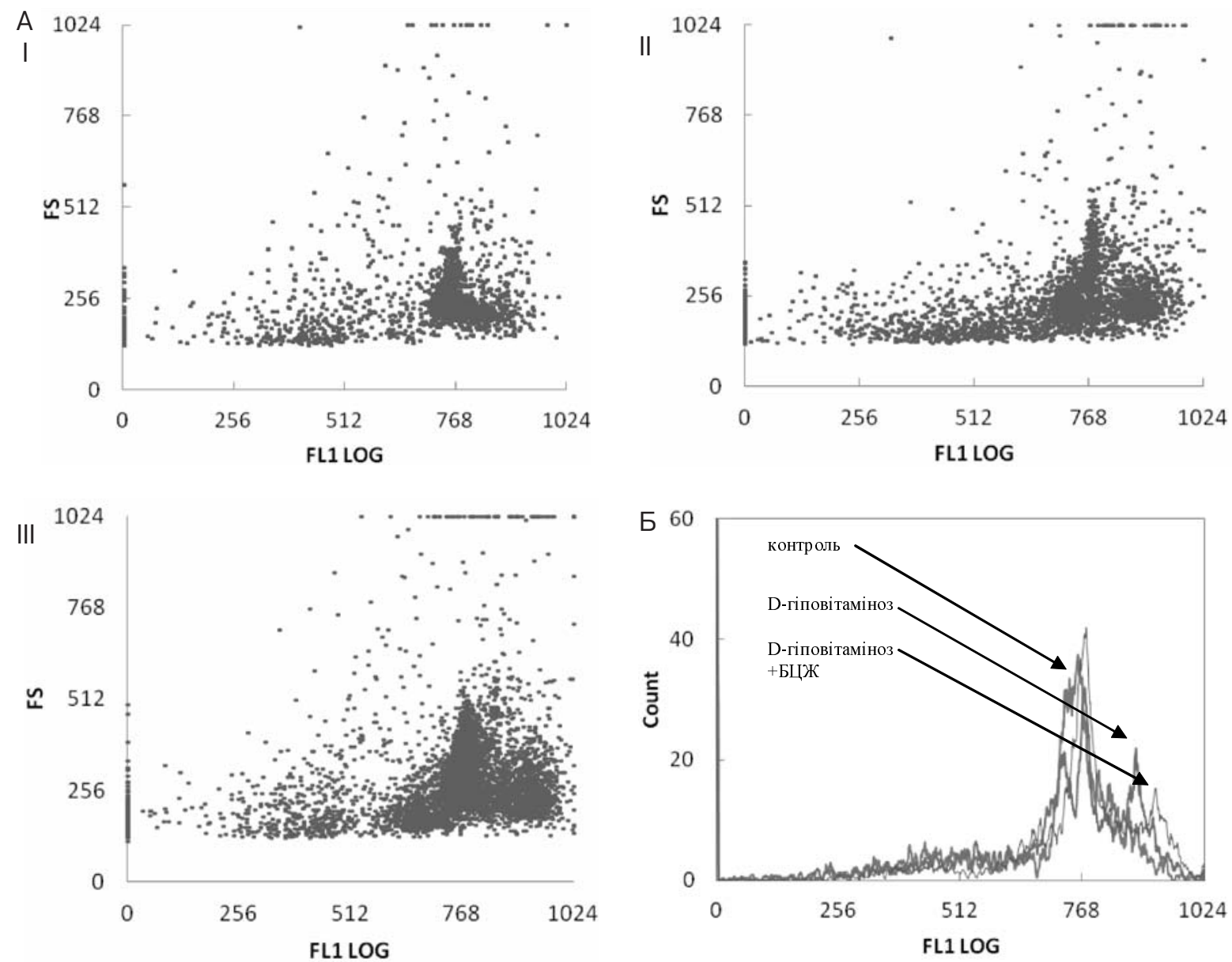

B

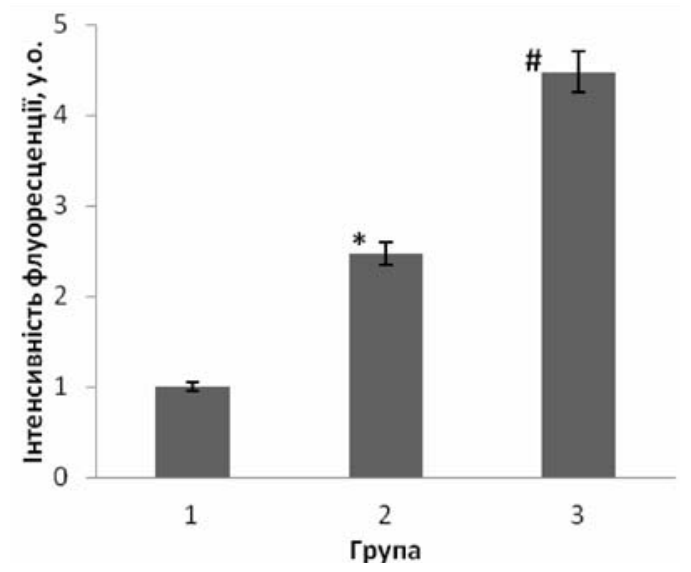

або такий, що продукується за рахунок Sнітрозо-N-ацетилпеніциламіну, послаблює як синтез NO, так і експресію MPHK iNOS та синтез самого ензиму. В міру підвищення рівня NO включається система зворотного зв'язку, що негативно впливає на активність ензиму та здатність NFкB зв'язуватися 3 ДНК. Цим досягається жорстка регуляція синтезу NO. Наявність цього негативного зворотного зв'язку забезпечує зниження накопичення NO в гепатоцитах, попереджуючи, тим самим, пошкоджувальну дію NO на тканину [9]. Таким чином, можна припустити, що в разі додаткової

Рис. 1. Цитофлуорограми утворення триазолофлуоресцеїну в лейкоцитах щурів за D-гіповітамінозу та введення вакцини БЦЖ (А, Б); кількісний аналіз цитофлуорограм (B): count - кількість подій, FL1LOG - інтенсивність флуоресценції; I - контроль, II - D-гіповітаміноз, III - D-гіповітаміноз+БЦЖ; * - результати, що достовірно відрізняються від 1-ї групи (контроль) $(\mathrm{p}(\mathrm{t})<0,05)$; \# - результати, що достовірно відрізняються від 2-ї групи (D-гіповітаміноз) $(p(t)<0,05)$.

індукції нітрозативного стресу на фоні аліментарного остеопорозу після суттєвого підвищення рівня NO відбувається послаблення експресії гена iNOS за рахунок активації системи негативного зворотного зв'язку високими концентраціями NO. Це призводить до гальмування окисних процесів та активації систем захисту клітин організму від пошкоджувальної діï NO.

Аналіз результатів остеометрії стегнової кістки свідчить про те, що введення вакцини БЦЖ не призвело до достовірних змін показників остеометрії порівняно з тваринами 3 
Таблиця 1 - Вміст компонентів оксидативно-нітрозативного стресу в плазмі крові та печінці

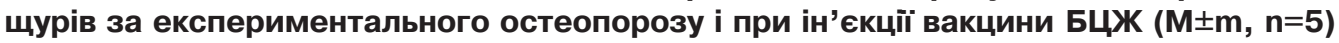

\begin{tabular}{|c|c|c|c|c|}
\hline \multicolumn{2}{|l|}{ Показник } & Контроль & D-гіповітаміноз & "D-гіповітаміноз+БЦЖ \\
\hline $\begin{array}{l}\text { Протеїнові карбонільні групи, } \\
\text { ум. од. }\end{array}$ & плазма & $1,0 \pm 0,04$ & $1,36 \pm 0,07^{\star}$ & $1,28 \pm 0,04^{\star}$ \\
\hline \multirow{2}{*}{$\begin{array}{l}\text { Загальний вміст альдегідів, } \\
\text { нмоль/мг протеїну }\end{array}$} & плазма & $0,6 \pm 0,1$ & $0,8 \pm 0,1^{*}$ & $0,9 \pm 0,1^{*}$ \\
\hline & печінка & $0,8 \pm 0,2$ & $1,1 \pm 0,2^{\star}$ & $0,7 \pm 0,1$ \\
\hline $\begin{array}{l}\text { ТБК-реагуючі продукти, } \\
\text { нмоль/мг протеїну }\end{array}$ & плазма & $0,5 \pm 0,1$ & $0,8 \pm 0,1^{*}$ & $0,7 \pm 0,2^{\star}$ \\
\hline $\begin{array}{l}\text { SH-групи низькомолекулярних } \\
\text { сполук, мкмоль/г тканини }\end{array}$ & печінка & $9,0 \pm 2,0$ & $6,9 \pm 1,3^{*}$ & $7,6 \pm 1,0^{*}$ \\
\hline $\begin{array}{l}\text { Супероксиддисмутаза, } \\
\text { Од/мг протеїну }\end{array}$ & кров & $70 \pm 11$ & $273 \pm 44^{\star}$ & $199 \pm 45^{\star}$ \\
\hline $\begin{array}{l}\text { Каталаза, } \\
\text { мкмоль } \mathrm{H}_{2} \mathrm{O}_{2} / \text { хв·мг протеїну }\end{array}$ & кров & $160 \pm 13$ & $263 \pm 26^{*}$ & $337 \pm 14^{\star \#}$ \\
\hline
\end{tabular}

Примітки. Тут і в таблиці 3:

1. * - результати, що достовірно відрізняються від 1-ї групи (контроль) $(\mathrm{p}(\mathrm{t})<0,05)$.

2. " - результати, що достовірно відрізняються від 2-ї групи (D-гіповітаміноз) $(p(t)<0,05)$.

розвиненим аліментарним остеопорозом (табл. 2).

Незміненими залишилися маса кістки, найбільша довжина та вертикальний діаметр головки стегнової кістки. Але відбулися досить суттєві зміни рівня показників мінерального обміну після індукції нітрозативного стресу (табл. 3). Загальний рівень кальцію та неорганічного фосфату, порівняно зі значеннями за аліментарного остеопорозу, підвищився на 22 та 25 \% відповідно. Зростання показників мінерального обміну під дією ендогенного синтезу NO на тлі остеопорозу корелювало зі зниженням загальної активності лужної фосфатази (на 40 \%). Однак це значення залишилося вищим порівняно з контролем (табл. 3).

Отримані результати свідчать про позитивний вплив NO на мінеральний обмін кісткової тканини за умов аліментарного остеопорозу в щурів. Як уже зазначалося, високі концентрації NO можуть призводити до NO-індукованого апоптозу попередників остеокластів або інгібувати їх формування та активність [18]. Одним із механізмів інгібування остеокластної активності оксидом азоту є модифікація катепсину К, який експресується остеокластами у великій кількості та відіграє ключову роль у кістковій резорбції, беручи безпосередню участь в деградації колагену кісткової тканини. Оксид азоту та деякі його донори інгібують активність катепсину К за рахунок окиснення тіолових залишків цього протеїну, що, у свою чергу, призводить до інгібування процесів резорбції кістки [23]. Також, за нашими припущеннями, позитивний ефект NO може бути пов'язаний зі стабілізацією колагену кісткової тканини, оскільки нітрозативний стрес, який виникає після введення вакцини БЦЖ, може посилювати утворення постсинтетичних зшивок за рахунок утворення додаткових внутрішньо- та міжмолекулярних зшивок у молекулі колагену і, таким чином, стабілізувати структуру остеона.

Таблиця 2 - Остеометричні показники стегнової кістки щурів за аліментарної форми

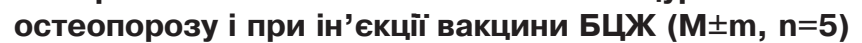

\begin{tabular}{||l|c|c|c|c||}
\hline \multicolumn{1}{|c|}{ Група тварин } & $\begin{array}{c}\text { Маса } \\
\text { тварини, г }\end{array}$ & $\begin{array}{c}\text { Маса } \\
\text { кістки, г }\end{array}$ & $\begin{array}{c}\text { Найбільша довжина } \\
\text { стегнової кістки, мм }\end{array}$ & $\begin{array}{c}\text { Вертикальний діаметр } \\
\text { головки стегнової } \\
\text { кістки, мм }\end{array}$ \\
\hline Контроль & $231 \pm 29$ & $0,68 \pm 0,06$ & $30,4 \pm 0,3$ & $3,6 \pm 0,3$ \\
\hline D-гіповітаміно3 & $99 \pm 14^{*}$ & $0,36 \pm 0,02^{*}$ & $20,6 \pm 0,6^{\star}$ & $3,1 \pm 0,0^{*}$ \\
\hline D-гіповітаміно3+БЦЖ & $97 \pm 21^{*}$ & $0,36 \pm 0,04^{\star}$ & $20,7 \pm 0,1^{\star}$ & $3,5 \pm 0,4$ \\
\hline
\end{tabular}

Примітка. * - результати, що достовірно відрізняються від 1-ї групи (контроль) $(p(t)<0,05)$.

Таблиця 3 - Мінеральний обмін та активність лужної фосфатази в плазмі крові щурів за аліментарної форми остеопорозу і при ін'єкції вакцини БЦЖ (M $\pm m, n=5)$

\begin{tabular}{||l|c|c|c||}
\hline \hline \multicolumn{1}{|c|}{ Група тварин } & $\begin{array}{c}\text { Загальна лужна } \\
\text { фосфатаза, Од/л }\end{array}$ & $\begin{array}{c}\text { Загальний кальцій, } \\
\text { ммоль/л }\end{array}$ & $\begin{array}{c}\text { Неорганічний фосфат, } \\
\text { ммоль/л }\end{array}$ \\
\hline Контроль & $134 \pm 22$ & $3,0 \pm 0,3$ & $1,9 \pm 0,2$ \\
\hline D-гіповітаміно3 & $291 \pm 50^{*}$ & $2,3 \pm 0,2^{*}$ & $0,4 \pm 0,1^{*}$ \\
\hline D-гіповітаміно3+БЦЖ & $173 \pm 17^{\star \#}$ & $2,8 \pm 0,1^{\#}$ & $0,5 \pm 0,1^{\star}$ \\
\hline
\end{tabular}


ВИСНОВКИ. Результати проведених досліджень свідчать про те, що утримування щурів на D-гіповітамінозному раціоні призводить до розвитку остеопорозу, який характеризується зменшенням маси тіла та маси стегнової кістки. Знижується рівень кальцію, фосфату та підвищується активність загальної лужної фосфатази у плазмі крові. За недостатньої забезпеченості вітаміном $\mathrm{D}_{3}$ та після введення вакцини БЦЖ достовірно зростає рівень NO в лейкоцитах тварин та індукується оксидативно-нітрозативний стрес. Індукований нітрозативний стрес призводить до змін інтенсивності мінерального обміну кісткової тканини щурів 3 аліментарним остеопорозом.

\section{СПИСОК ЛІТЕРАТУРИ}

1. Алексеев В. П. Остеометрия. Методика антропологических исследований / В. П. Алексеев. М. : Наука, 1966. - 251 с.

2. Дмитренко Н. П. Роль взаимодействия путей метаболизма формальдегида и оксида азота в механизме их токсического действия. І. Экзо- и эндогенные источники формальдегида и оксида азота. Токсическое действие формальдегида / Н. П. Дмитренко, А. Холиан // Укр. биохим. журн. 2005. - 77, № 1. - С. 22-31.

3. Ефективність біофармацевтичного препарату "Мебівід" у попередженні порушень обміну вітаміну $\mathrm{D}_{3}$ та кальцію за аліментарного остеопорозу / С.В.Комісаренко, Л. І. Апуховська, В.М.Рясний [та ін.] // Біотехнологія. - 2011. - 4, № 1. - С. 74-81.

4. Зайцева О. В. Модифікація спектрофотометричного методу визначення карбонільних груп протеїнів / О. В. Зайцева, С. Г. Шандренко // Укр. біохім. журн. - 2012. - 84, № 5. - С. 112-116.

5. Імуномодулююча дія вітаміну $\mathrm{D}_{3}$ та бісфосфонатів при аліментарному остеопорозі в щурів / В. М. Рясний, Л. І. Апуховська, М. М. Великий [та ін.] // Укр. біохім. журн. - 2012. - 84, № 2. C. $73-80$.

6. Лущак В. И. Свободнорадикальное окисление белков и его связь с функциональным состоянием организма / В. И. Лущак // Биохимия. 2007. - 72, № 8. - С. 995-1017.

7. Особливості перебігу процесів пероксидного окислення біомолекул у печінці щурів за недостатньої забезпеченості вітаміном $\mathrm{D}_{3} / \mathrm{M}$. М. Великий, О. В. Зайцева, І. О. Шиманський [та ін.] // Біологічні системи. Науковий вісник Чернівецького університету (Біологія). - 2013. - 5, № 4. - С. 287-294.

8. Серая И. П. Современные представления о биологической роли оксида азота / И. П. Серая, Я. Р. Нарциссов // Усп. совр. биологии. - 2002. 122, № 3. - С. 249-258.

9. Тейлор Б. С. Индуцибельная синтаза оксида азота в печени: регуляция и функции / Б. С. Тейлор, Л. Х. Аларсон, Т. Р. Биллиар // Биохимия. - 1998. 63, № 7. - С. 905-923.

10. Шандренко С. Г. Синтез оксида азота у крыс при инъекции вакцины БЦЖ / С. Г. Шандренко,
Н. П. Дмитренко // Укр. биохим. журн. - 2001. -73 № 3. - С. 55-60.

11. Aktan F. iNOS-mediated nitric oxide production and its regulation / F. Aktan // Life Science. - 2004. 75. - P. 639-653.

12. High sensitivity enzyme-linked immunosorbent assay (ELISA) method for measuring protein carbonyl in samples with low amounts of protein / D. H. Alamdari, E. Kostidou, K. Paletas [et al.] // Free Radic. Biol. Med. - 2005. - 39, № 10. - P. 1362-1367.

13. Hu M. L. Measurement of protein thiol groups and glutathione in plasma / M. L. Hu // Methods Enzymol. - 1994. - 233. - P. 380-385.

14. Inducible nitric oxide synthase mediates bone development and $\mathrm{P}$. gingivalis-induced alveolar bone loss / R. Gyurko, H. Shoji, R. A. Battaglino [et al.] // Bone. - 2005. - 36. - P. 472 - 479.

15. Indusible nitric oxide synthase mediates bone loss in ovariectomized mice / S. Cuzzocrea, E. Mazzon, L. Dugo [et al.] // Endocrinology. - 2003. - 144, № 3. P. 1098-1107.

16. Intracellular nitric oxide assessment in whole blood leukocytes by flow cytometry: Optimization and applicability to monitor patients with chronic graft nephropathy / N. C. C. Schachnik, V. Peruhype-Magalhaes, G. M. M. Paula [et al.] // Journal of Immunological Methods. - 2009. - 343. - P. 103-111.

17. Janero D. R. Malondialdehyde and thiobarbituric acid-reactivity as diagnostic indices of lipid peroxidation and peroxidative tissue injury / D. R. Janero // Free Rad. Biol. Med. - 1990. - 9, № 6. - P. 515-540.

18. Kim P. K. The regulatory role of nitric oxide in apoptosis / P. K. Kim, R. Zamora, P. Petrosko // International Immunopharmacology. - 2001. - 1, № 8. - P. 1421-1441.

19. Lee C. H. Quantification of bacterial lipopolysaccharides by the purpald assay: Measuring formaldehyde generated from 2-keto-3-deoxyoctonate and heptose at the inner core by periodate oxidation / C. H. Lee, C. M. Tsai // Anal. Biochem. - 1999. -267. P. $161-168$.

20. Role of antioxidant systems, lipid peroxidation, and nitric oxide in postmenopausal osteoporosis / S. Ozgocmen, H. Kaya, E. Fadillioglu [et al.] // Molecular and Cellular Biochemistry. - 2007. - 295. - P. 45-52. 
21. The chemical biology of nitric oxide: implications in cellular signaling / D. D. Thomas, L. A. Ridnour, J. S. Isenberg [et al.] // Free Radic. Biol. Med. 2008. - 45. - P. 18-31.

22. Use of diaminofluoresceins to detect and measure nitric oxide in low level generating human immune cells / A. Tiscornia, E. Cairoli, M. Marquez [et al.] // Journal of Immunological Methods. - 2009. 342. - P. 49-57.

23. Van't Hof R. J. Nitric oxide and bone / R. J. Van't Hof, S. H. Ralston // Immunology. - 2001. 103. - P. 255-261.

О. В. Зайцева, С. Г. Шандренко, Н. Н. Великий ИНСТИТУТ БИОХИМИИ ИМЕНИ А.В. ПАЛЛАДИНА НАН УКРАИНИ, КИЕВ

\section{ВЛИЯНИЕ НИТРОЗАТИВНОГО СТРЕССА НА МИНЕРАЛЫНЫЙ МЕТАБОЛИЗМ КОСТНОЙ ТКАНИ КРЫС ПРИ АЛИМЕНТАРНОМ ОСТЕОПОРОЗЕ}

\section{Резюме}

На модели алиментарного остеопороза исследовали влияние индуцированного нитрозативного стресса на метаболизм костной ткани крыс. В качестве индуктора нитрозативного стресса использовали вакцину БЦЖ. Показано, что витамин $D_{3}$-дефицитный остеопороз при введении вакцины БЦЖ приводит к развитию оксидативно-нитрозативного стресса у крыс, интенсивность которого регистрировали по накоплению NO в лейкоцитах, изменению содержания альдегидов, продуктов пероксидного окисления липидов, SH-групп низкомолекулярных соединений и карбонильных групп протеинов. Установлено, что интенсификация синтеза NO на фоне остеопороза вызывает изменения интенсивности минерального обмена костной ткани. Стабилизируется уровень кальция и снижается активность щелочной фосфатазы. Полученные результаты свидетельствуют о том, что высокие концентрации NO влияют на функционирование клеток костной ткани и тормозят процесс резорбции кости.

КЛЮЧЕВЫЕ СЛОВА: остеопороз, витамин $\mathrm{D}_{3}$, БЦЖ, нитрозативный стресс, костная ткань.

O. V. Zaitseva, S. G. Shandrenko, M. M. Veliky O. V. PALLADIN INSTITUTE OF BIOCHEMISTRY OF NAS OF UKRAINE, KYIV

\section{EFFECT OF NITROSATIVE STRESS ON THE BONE MINERAL METABOLISM OF RATS UNDER ALIMENTARY OSTEOPOROSIS}

\section{Summary}

On the alimentary osteoporosis model it was investigated the effect of induced nitrosative stress on bone metabolism in rats. As nitrosative stress inducer BCG vaccine was used. It was shown that the vitamin $D_{3}$-osteoporosis under BCG vaccine administration leads to the oxidative-nitrosative stress development. In this condition the level of NO in leukocytes, total content of aldehydes, products of lipid peroxidation, low-molecular weight SH-groups and protein carbonyl groups was determined. It was established that the intensification of NO synthesis under alimentary osteoporosis led to the changes in the bone mineral metabolism intensity. It was stabilized the calcium level and reduced the alkaline phosphatase activity. Obtained results indicated that NO high concentrations influence on the bone cells functioning and inhibition of bone resorption process.

KEY WORDS: osteoporosis, vitamin D $_{3}$, BCG, nitrosative stress, bone tissue.

Отримано 16.10.14

Адреса для листування: О. В. Зайцева, Інститут біохімії імені О. В. Палладіна НАН України, вул. Леонтовича, 9, Київ, 01610 , Україна, e-mail: Zaitseva_OV@ukr.net. 